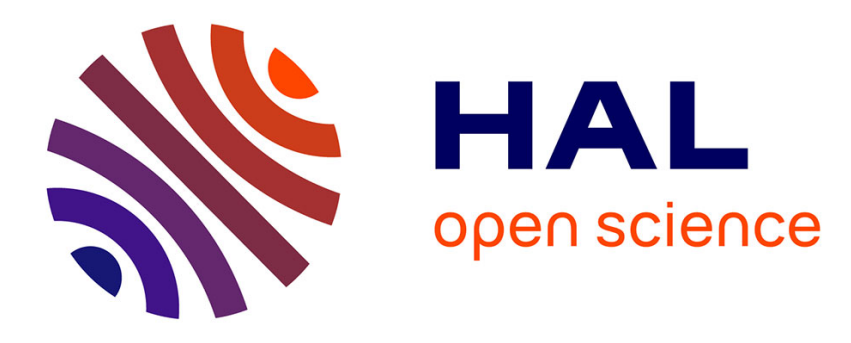

\title{
Analytical study of Bronze Age goldwork from Northwest Iberia
}

Maria Guerra, Isabel Tissot

\section{To cite this version:}

Maria Guerra, Isabel Tissot. Analytical study of Bronze Age goldwork from Northwest Iberia. Journal of Archaeological Science: Reports, 2021, 39, pp.103117. 10.1016/j.jasrep.2021.103117 . hal03325348

\section{HAL Id: hal-03325348 \\ https://hal.science/hal-03325348}

Submitted on 27 Nov 2021

HAL is a multi-disciplinary open access archive for the deposit and dissemination of scientific research documents, whether they are published or not. The documents may come from teaching and research institutions in France or abroad, or from public or private research centers.
L'archive ouverte pluridisciplinaire HAL, est destinée au dépôt et à la diffusion de documents scientifiques de niveau recherche, publiés ou non, émanant des établissements d'enseignement et de recherche français ou étrangers, des laboratoires publics ou privés. 


\title{
Analytical study of Bronze Age goldwork from Northwest Iberia Journal of Archaeological Science: Reports, 39, 2021, 103117 \\ https://doi.org/10.1016/j.jasrep.2021.103117
}

\author{
Maria Filomena Guerra ${ }^{1}$, Isabel Tissot ${ }^{2}$ \\ ${ }^{1}$ MONARIS, UMR 8233 CNRS - Sorbonne Université, Paris, France, maria.guerra@cnrs.fr \\ ${ }^{2}$ LIBPhys-UNL, Universidade NOVA de Lisboa, Portugal, isabeltissot@fct.unl.pt
}

\begin{abstract}
The production of goldwork in Northwest Iberia in the Bronze Age was approached in this work by studying seven bracelets and two sheet collars (gargantilha de tiras) from different sites located in Galicia (Spain) in the collection of the Provincial Museum of Lugo. Among the studied objects are the two sheet collars and one bracelet that constitute the Treasure of Monte dos Mouros and the two bracelets contained in the Treasure of A Urdiñeira. The in-situ study has included the observation of the manufacture details of the objects under a stereomicroscope and the determination of their elemental composition using an in-house built portable X-ray fluorescence spectrometer. Data obtained provided new insight into the objects, revealing the use of traditional Bronze Age technologies and for some of them new manufacturing details. One of the bracelets from A Urdiñeira has a twophase decoration and signs of wear, unlike the necklaces from Monte dos Mouros, which have no signs of wear. To put the objects in context and shed new light on questions related to the chronology of some of them, the elemental compositions obtained are compared with data published for other gold pieces from Galicia, showing the regular use of native gold and, in some periods, of two sorts of intentional gold alloys.
\end{abstract}

Keywords: Bronze Age; NW Iberia; gold alloys; bracelets; sheet collars

\section{Introduction}

The analysis of Portuguese gold bracelets dated to the Middle (MBA) and Late (LBA) Bronze Age (BA) (Tissot and Guerra, 2017), has shown compositional variations associated with chronological and regional practices. Since extensive gold deposits occur in the Iberian Peninsula (Lehrberger, 1995; Sánchez Palencia et al. 1996; Boiron and Cathelineau, 1999; Borg, 2010; Fernández-Lozano et al. 2019), these differences may have been caused by the use of both native and intentional gold alloys.

Although gold occurs as native in primary deposits (most commonly hosted by quartz veins), the earliest exploited gold deposits are allegedly alluvial, because gold is recovered by simple panning and washing (Healy, 1979). Formed by gold-bearing debris from weathering, desegregation and leaching of primary deposits followed by transportation and concentration by gravity (Boyle, 1969; Boyle 1979; Stanaway, 2012), the recovered nuggets, flakes and dust are gold-silver-copper alloys of quite variable compositions (Arndt et al., 2015; Butt et al., 2020). Although occurrences of native gold with more than $1 \mathrm{wt} \% \mathrm{Cu}$ are sporadic (Moles et al., 2013; Chapman et al., 2020), silver typically ranges from 5 up to $30 \mathrm{wt} \%$ (Allan and Woodcock, 2001), reaching in some deposits 40-50 wt\% or more (Boyle, 1969; Boyle, 1979; Jones and Fleischer, 1969, Hough et al., 2009; Spiridonov and Yanakieva, 2009; Chapman and Mortensen, 2016). High silver contents contained in native gold may thus be used to explain the composition of early objects, e.g. from Varna (Hartmann, 1982; Echt et al., 1991; Leusch, 2019), Ur (Plenderleith, 1934; Hauptmann et al., 2018) and Egypt (Gale and Stos-Gale, 1981; Guerra, 2018; Guerra 2021). Already in the 1880s, the brothers Siret pointed out the use of silver-rich gold alloys (Siret and Siret, 1988) at El Argar and Fuente Alamo in Southeast Spain (Siret and Siret, 1887; Montero-Ruiz et al. 2019). However, although goldwork is seldom found in Chalcolithic contexts (Lilios, 2019), the earliest objects show lower silver contents (e.g. Murillo-Barroso et al., 2015; Rovira et al., 2015; Guerra and Tissot, 2016; Valério et al. 2017): up to $20 \mathrm{wt} \%$ $\mathrm{Ag}$ and (as suggested by Perea, (1991) and Blasco and Ríos (2010) in average up to $0.1 \mathrm{wt} \% \mathrm{Cu}$. Indeed, among the 143 results provided in Murillo-Barroso et al., 2015; Rovira et al., 2015; Guerra and Tissot, 2016, Valério et al. 2017 only eight (three from Cerro de la Virgen analysed by Hartmann (1982) as pointed out by Perea (1991) show higher contents than the average value of $0.17 \mathrm{wt} \% \mathrm{Cu}$ obtained by Moles et al. (2013) for 500 gold grains. The extensive gold deposits that occur in the Iberian Peninsula (Castroviejo, 1995; Martins, 2008; Inverno, 2011) were early exploited (Harrison, 1931; Allan, 1965; Domergue, 1990) and may explain the regional (north/south of River Tagus) variation of the silver amounts observed for objects made from the EBA onwards, including the mentioned Portuguese bracelets. To explain the copper contents, technological evolutions should also be taken into account. In the LBA, when forming by lost wax casting and assembling by hard soldering started to be implemented, intentional gold alloys may have started to be regularly produced. This allows control of the mechanical and physical properties of the alloys, including the optical ones (e.g. colour, reflectivity). It is conceivable at the beginning a search for native gold alloys with distinct aesthetical and/or metallurgical properties according to the use and selected by colour (naturally occurring with different silver amounts), alike for example 
in Egypt (Harris, 1961; Guerra, 2021). Then, addition of small amounts of copper and/or silver to these alloys (of different 'sorts'/colours) may have been done.

All the mentioned arguments can be used to explain the compositional variations observed for BA Iberian goldwork. As gold metallurgy could have had a regional development, we concentrate our studies on one of the richest gold mining regions, the Northwest (NW) Iberia (Monteagudo, 1953; Noronha and Ramos, 1993; Spiering et al., 2000; MacKenzie et al. 2019). In order to provide an insight into the gold alloys employed in NW Iberia during the $\mathrm{BA}$ and contribute to the understanding of the manufacture technologies locally employed, we have submitted in this work to science-based study nine objects in the collection of the Provincial Museum of Lugo in Spain. The objects are all from sites situated in Galicia and are typical of the local practices. They were examined in-situ with a stereomicroscope and the composition of their gold alloys was obtained by using a portable X-ray fluorescence (XRF) spectrometer.

Among the analysed objects, listed in Table 1 and shown in Figure 1 are the two sheet collars (gargantilha de tiras) and one bracelet contained in the Treasure of Monte dos Mouros and the two bracelets from the Treasure of A Urdiñeira (Balseiro García, 2018). For some of them we only describe unpublished manufacturing details. In this work, we focus more on the composition of the gold alloys. Further insight is provided in the light of published data for EBA to Iron Age (IA) goldwork from Galicia and neighbouring regions allowing us for some of the studied objects to shed new light on questions related to their period of manufacture.

\section{Methods and instrumentation}

The objects were examined in-situ using a SMZ1 Nikon stereomicroscope. For image acquisition and storage, the microscope was equipped with an AM7023 series eyepiece camera from Dino-Lite (5 MP resolution and allowing $72.5 \mathrm{x}$ the magnification rate of the objective) connected via USB to a PC.

The elemental composition of the alloys was determined by using an in-house portable XRF spectrometer in a planar configuration designed and built at LIBPhys-UNL for in-situ analysis of objects included in projects focusing on Cultural Heritage (Guerra et al., 2014). The spectrometer comprised an Amptek Eclipse II X-ray tube system with an $\mathrm{Ag}$ anode set to $30 \mathrm{kV}$ and $20 \mu \mathrm{A}$, an Amptek MC8000A Pocket MCA multichannel analyser, and an Amptek XR-100CR Si-PIN detector with a $25 \mu \mathrm{m}$ Be window and with energy resolution of $190 \mathrm{eV}$ at $5.9 \mathrm{keV}$. A $2 \mathrm{~mm}$ diameter Ta collimator reduces the spot beam size to $4 \mathrm{~mm}$ at the surface of the sample and the two alignment lasers provide proper positioning of the sample. Spectra were processed using WinAxil software (Vekemans et al., 1994). The accuracy of the quantitative results was validated by analysis of a set of home-made gold alloys containing 0.2 to $24.6 \mathrm{wt} \% \mathrm{Ag}$ and 0.1 to $4.9 \mathrm{wt} \% \mathrm{Cu}$ (Tissot et al., 2013).

The composition of the studied objects is reported in Table 2. No PGE (platinum group elements) inclusion was identified at the surface of the objects. The presence in gold alloys of $\mathrm{Sn}$ and $\mathrm{Pt}$ is considered as an indicator of the use of alluvial gold (Guerra, 2004; Dube, 2006; Guerra, 2008; Guerra and Tissot, 2016; Guerra, 2018). However, low contents of these elements are difficult to be accurately determined (Guerra, 2008; Radtke et al., 2016) and could not be analysed.

\section{The analysed objects: origin and manufacture 3.1 The Treasure of Monte de Mouros}

One gold bracelet and two gold sheet collars (nos. 4, 8 and 9 in Table 1, Fig.1C) constitute the Treasure of Monte dos Mouros, fortuitously found in 1887 at San Martino de Oleiros (Toques, A Coruña). With an archaeological context imprecisely recorded and containing originally an unknown number of objects (Balseiro García, 1992; Comendador Rey, 1998), the Treasure was discovered in a site that may have been under the influence of EBA or IA settlements (Ladra et al., 2003).

The two sheet collars are typical productions of the Atlantic façade, equivalents were found in Galicia, in northcentral Portugal and in western France (Eluère 1982; Eluère, 1983; Balseiro García, 1992; Armbruster, 2000; Ladra et al., 2003). These items, which are a sign of social differentiation that can be included in the EBA (Cardoso, 2014; Cardoso, 2014-2015), were described by several authors (Eluère 1977; Eluère 1982; Eluère, 1983; Armbruster et al. 2004) With parallel bands cut in the sheet front, they are all made from a single rectangular gold sheet rolled into a cylindrical shape, often decorated with dots punched using previously incised alignment lines. EBA neck-rings (lunulae) from the British Isles (BI) were decorated using the same technique (Taylor, 1969). Some sheet collars have holes for fastening, such as the one from Saint Laurs in France (Eluère, 1977; Eluère, 1982) of Atlantic type (Gomez de Soto, 1999).

The front of the largest sheet collar (no. 8) from Monte dos Mouros was cut in fourteen strips and the smallest one (no. 9) originally in eight, but today one strip is missing. The latter has two holes at each terminal and, additionally, on one side two half holes and on the other side one-half hole. The terminals were aligned in Figure 2 to show that the two middle half holes may correspond to one original hole. On the front sheet, the strip cutting tool marks overlap the punched dots in both collars indicating the course of the goldsmith's work. The vertically aligned triple rows of dots punched along the alignment lines on both collars are two made from the inside and one made from the outside (Fig. 2B). Finally, it is noticeable that the many hammering folds on the back sheet were not rubbed 
out and some of the strips were incompletely cut or still contain cutting leftovers (Fig. 2C). These features and the absence of use-wear marks suggest that the ornaments have been barely (or not) worn.

The Treasure also comprises one thin cast gold penannular bracelet (no. 4) of undetermined chronology, but that is said to be more recent (Balseiro García, 2003-2004). Exhibiting signs of overheating, the bracelet is decorated with five ribs that reproduce three twisted wires between plain wires. The quite inaccurate motif shows clear angle changes of the tool when incising the wax (Fig. 3). The hook-and-loop fastening system (Fig. 3) is of a type that has been observed in a few other bracelets (Balseiro García, 1992). The most similar bracelet, decorated with four central twists and two plain ribs, was found at Saint-Marc-le-Blanc (France) (Menez et al., 2005). This bracelet, said to evoke NW Iberia goldwork (Eluère, 1982; Eluère 1986), is dated to the IA, because found with, among other objects, one three-strand gold ribbon torc and a small ring similar to the LBA-early IA ring (Eluère, 1990) found in an undefined context (Gandois and Barthet, 2015) at Saint Père-en-Retz (France). Cahill (2006), who also dates the French bracelet to the IA by comparison with the one from Dunhallow (Cork, BI), refers however, that the MBA bracelet excavated at Burton (Wrexham, BI, (Murgia et al., 2014)) is stylistically similar.

\subsection{The Treasure of A Urdiñeira}

The Treasure of A Urdiñeira was found by accident in 1921 by a shepherdess at Parada da Serra (A Gudiña-Rios, Ourense). This decontextualized hoard (Comendador Rey and Méndez Fernández, 2009) contained one bronze disc and the two gold bracelets studied in this work. Dated to the MBA (Cuevillas and Bouza Brey, 1992) and on stylistic grounds to the IA (Perea, 2005), the Treasure was recently dated to the LBA (Armbruster and Comendador Rey, 2015).

One of the bracelets (no.2, Fig. 1A) is a ribbed tubular piece made by lost wax casting. It is decorated with ten ribs and sequences of vertical lines incised in the grooves. The other bracelet is penannular (no.3, Fig. 1A). It consists of a thick gold band decorated with geometric motifs and pierced at both ends. Both the band and the holes show marks of use-wear, suggesting that it did not had a funerary or votive function only. The bracelet is decorated along the borders with a chased herringbone pattern and in the terminals with hatched triangles. However, possibly different goldsmiths made the triangles, in two phases. Those that decorate one of the terminals have thin engraved contours overlapped by thin chased hatching lines (Fig. 4A) whilst on the other terminal the deeply chased contours overlap the thin hatching lines and apparently the original thin contour (Fig. 4B). The later seem to be made during the same phase of decoration of the herringbone pattern, because this pattern is also deeply and unevenly made, every so often overlapping the deeply engraved parallel lines (Fig. 4C).

Two phases or attempts of decoration were identified in BI lunalae dated to the EBA (Taylor, 1980). Like the bracelet from A Urdiñeira, the lunula from Ballinagroun (Kerry, Ireland), classical in form, has a second series of decoration applied over a more skilled classical design (Taylor, 1979). NW Iberian objects have been associated to BI productions (Maluquer de Motes, 1970), and the bracelet evokes the LBA bronze penannular bracelets from Senhora da Guia (Baiões, NW Portugal) decorated with hatched triangles (Silva et al., 1984), most likely made locally with parallels in BI productions (Silva, 1986), as suggested for other Iberian objects (Pingel, 1991; Taylor, 1994).

\subsection{The other gold bracelets}

Four other bracelets were studied in this work. Such as one of the bracelets from A Urdiñeira, two of the four are ribbed tubular bracelets made by lost wax casting. One of these (no. 1, Fig. 1E), decorated with four ribs, was found at San Martiño de Oleiros, Toques (A Coruña) and dated both to the LBA (Armbruster, 2000) and the IA (Perea, 2005). The other (no.7, Fig.1B), a decontextualised find from Ourense dated to the LBA (Balseiro García, 1992), is decorated with four rows of conical spikes alternating with groups of two plain ribs. These bracelets are identical to other Villena/Estremoz (VE) type bracelets (Russel, 1954; Almagro-Gorbea, 1974; Almagro-Gorbea, 1995; Perea, 2005). Their manufacture technologies were described in detail by several authors, including the use of a circular tool to make the conical spikes (Armbruster and Perea, 1994; Armbruster, 1995), shown in Figure $5 \mathrm{~A}$.

The remaining two bracelets studied in this work were found at Moimenta (Couto dos Castros, Arnois, A Estrada, Pontevedra) (nos. 5 and 6 in Table 1, Fig. 1D). Of undefined chronology, they were dated to both the LBA (Balseiro García, 2003-2004) and the IA (Armbruster, 2000). These gold sheet penannular bracelets, look like a pair. Four components frame a hammered gold sheet band. The superposition of the body and frame sheets is apparent on the back (Fig. 5B). The ribbed decoration of the bracelets represents concentric rectangles, and the decoration of the frame components consists of four thin plain ribs. In some way, their decoration evokes central European pieces (e.g. the bracelets from Ocihov and Minice in Check Republic (Moucha, 2005) and those from Dieskau in Germany (Meller, 2019).

\section{The gold alloys}

Table 2 summarises the data obtained by XRF for the elemental composition of the studied objects. The values represent the average of three or four consecutive analyses. The results obtained are discussed below. 


\subsection{The sheet collars from Monte de Mouros}

The two sheet collars from Monte de Mouros contain $0.2 \mathrm{wt} \% \mathrm{Cu}$ and different amounts of silver. Based on the Iberian Chalcolithic gold alloys mentioned above, we can say that their silver contents are included in the range expected for the earliest productions, made from native gold.

Quite few analytical data on EBA gold sheet objects from Galicia are available for comparison. Indeed, the sheet collars with cut bands from Agolada (Pontevedra) and Cícere (A Coruña) were not yet analysed for the composition of their alloys, only the gold sheet diadem from Vilavella de Puentes de García Rodrígues (A Coruña) was analysed by Hartmann (1982). Therefore, we considered in this comparison the sheet collar with cut bands from Quinta do Vale de Moinhos (central Portugal, (Ladra et al., 2003)), analysed by Hartmann (1982), who also analysed the two ribbed sheet gold pieces found in a cist at Atios (Porriño, Pontevedra) with two daggers and two silver spirals and the diadem found in a similar cist (Brandherm 2007; Harrison, 1974) at Quinta da Água Branca (NW Portugal). The objects were plotted in the diagram of Figure 6. They all contain less than $0.2 \mathrm{wt} \% \mathrm{Cu}$, such as the Chalcolithic objects mentioned above. The gold rings and spirals found with the diadem at Quinta da Água Branca, not plotted, contain $0.03-0.06 \mathrm{wt} \% \mathrm{Cu}$, which confirms the low copper contents in the gold. The silver contents observed for the objects range from c. 13 to $22 \mathrm{wt} \%$, but only the two pieces from Atios contain more than $20 \mathrm{wt} \% \mathrm{Ag}$. The amounts of silver and copper observed are thus those expected for native gold alloys, and similar to those published for Iberian Chalcolithic goldwork.

\subsection{The bracelets from Monte dos Mouros and A Urdiñeira}

The cast bracelet from Monte dos Mouros (no. 4), of undefined chronology, was added to the diagram of Figure 6 with those from A Urdiñeira. We can observe that all of them contain silver amounts identical to those observed for the early NW objects made from native gold. However, the low copper contents are different. If the penannular bracelet from A Urdiñeira (no.3) contains lower amounts than the other bracelets $(0.2 \mathrm{wt} \% \mathrm{Cu}$ like the earliest objects), the other bracelet from the same hoard (no.2) and the bracelet from Monte dos Mouros contain 0.5-0.6 wt $\% \mathrm{Cu}$.

Based on the decoration of the penannular bracelet and on the copper contents, it is tempting to consider that the two bracelets from A Urdiñeira represent different metallurgical 'stages'. In order to check whether this small compositional difference may be significant, we plotted in the diagram of Figure 7 the mentioned objects with the solid penannular bracelets with round- and rectangular-shaped sections from Galicia analysed by Hartmann (1982). Twenty bracelets and five larger rings (Pingel, 1992) are from Caldas de Reis hoard 1 (As Silgadas, Pontevedra (Castro and Comendador Rey, 1998), dated to the EBA (Ruiz-Galvez, 1995) and to the MBA (Almagro-Gorbea, 1997), but perhaps containing pieces covering a large period (Perea and Armbruster, 2008). Two others, dated to the MBA (Bettencourt, 2010), are from the Treasure of Agolada. None of these bracelets contains more than 0.2 $\mathrm{wt} \% \mathrm{Cu}$. The silver contents show a large variety, but in the range expected for unrefined native gold, and only one bracelet contains less than $c .7 \mathrm{wt} \%$ Ag. Only the bracelet from Monte dos Mouros and the tubular bracelet from A Urdiñeira contain more than $0.2 \mathrm{wt} \% \mathrm{Cu}$.

The hoard of As Silgadas also contained gold sheet fragments perhaps from an early sheet collar (Pingel, 1992; Ladra et al., 2003). The approximate concentrations provided by Hartman (1982) for the sole fragment analysed were added to the diagram, showing that it contains, contrary to the bracelets and such as the two pieces from Atios, more than $20 \mathrm{wt} \% \mathrm{Ag}$, which goes with a possible chronological difference.

\subsection{The bracelet from Toques and the Ourense bracelet}

The bracelet from Toques (no.1, Fig.1E) and the Ourense bracelet (no.7, Fig1B) are later productions, associated to the VE type, such as the tubular cast bracelet (no. 2, Fig.1A) from A Urdiñeira (Balseiro García, 1992; Perea, 1995; Armbruster, 2000; Comendador Rey et al., 2011), which, as mentioned, contains higher $\mathrm{Cu}$ amounts. The three contain c. $10-13 \mathrm{wt} \% \mathrm{Ag}$, but if the bracelet from A Urdiñeira contains $0.6 \mathrm{wt} \% \mathrm{Cu}$ those from Toques and Ourense contain 0.2 and $0.3 \mathrm{wt} \% \mathrm{Cu}$, respectively, values expected for local native gold.

We considered important to compare the composition of these three bracelets with the composition of other VE type bracelets from NW Iberia. According to Perea (2005) and Pérez-Romero et al. (2018), the most representative ones are, with the Ourense bracelet, those from Chaves (Portugal), Toén (Spain), and Monte da Saia (Barcelos, Portugal). The bracelets from A Urdiñeira, Toques, Cantonha (Guimarães, Portugal) and Lebução (Valpaços, Portugal) are considered IA evolutions of VE type bracelets. The ribbed tubular bracelet from Monte da Saia (with rows of circles in the grooves, (Cardozo, 1957)) and the bracelet from Lebução (richly decorated with floral and geometric motifs, (Molina, 1996; Martins, 2010)) were analysed by Hartmann (1971). Tissot and Guerra (2017) recently reassessed the bracelet from Cantonha for the composition of the three distinct components. Indeed, this composite object consists on a VE type bracelet decorated with two rows of spike-shaped elements between two decorated Sagrajas/Berzocana type penannular bracelets with expanded terminals such as some Irish LBA items (Pingel, 1991). 
The bracelets are plotted in Figure 8 with the cast tubular VE type bracelet from Cueva del Silo (Burgos, north of Spain) recently analysed (Pérez-Romero et al., 2018). The bracelet from Lebução (more recent (Pingel, 1991)) contains very high silver (30 wt\%) and copper ( $5 \mathrm{wt} \%$ ) contents, an intentional gold alloy that may result from either difficult access to gold (Molina, 1996) or an aesthetical choice. The bracelet from Cueva del Silo contains, in opposition, very low silver and copper contents, which may be caused by exploitation of different gold deposits in the province of Burgos. All the other bracelets represented in the diagram contain similar silver values, but different copper contents. The bracelets from Monte da Saia and Ourense, considered VE type productions, contain 0.1-0.3 wt \% Cu and match in elemental composition the other objects. The tubular bracelet from A Urdiñeira contains $0.6 \mathrm{wt} \% \mathrm{Cu}$ and the bracelet from Cantonha contains $c .1 \mathrm{wt} \% \mathrm{Cu}$. These two bracelets are considered, with those from Lebução and Toques, IA evolutions (Perea, 2005). However, if the bracelet from Lebução is clearly made from a very different alloy, the bracelet from Toques only contains $c .12 \mathrm{wt} \% \mathrm{Ag}$ and $0.2 \mathrm{wt} \% \mathrm{Cu}$, amounts expected for local native gold.

To go further in the discussion of the gold alloys, we considered in the diagram of Figure 8 the mentioned bracelets, with the exception of the one from Lebução, with the most representative VE bracelets found in Iberia that were analysed by Hartmann (1982). One of them is the bracelet from Estremoz (Évora), found in Portugal, and all the others were found in Spain. Those in the hoard from Villena are decorated with ribs, spike-elements and interspaced perforations (Schüle, 1976; Soler García 1965; Soler García, 1969); the hoard of Cabezo Redondo contains one fragment with spike-elements supposedly from a bracelet (Soler García, 1969; Soler García 1965; Pingel, 1992); and at Abia de la Obispalía were found four bracelets (Galán, 2017), two of them with ribs and inter-spaced perforations.

None of these bracelets has either the high $\mathrm{Ag}$ and $\mathrm{Cu}$ contents observed for the bracelet from Lebução or the low Ag contents observed for the bracelet from Cueva del Silo, and only the fragment from Cabezo Redondo matches the copper contents observed for the bracelet from Cantonha. The bracelets from Villena contain 4 to $13 \mathrm{wt} \% \mathrm{Ag}$, and those from Abía de la Obispália more than $10 \mathrm{wt} \% \mathrm{Ag}$. We can also observe in the diagram that the majority of the items contain up to $0.4 \mathrm{wt} \% \mathrm{Cu}$, where the bracelets from Toques and Ourense are included. Only a few bracelets contain more than $0.4 \mathrm{wt} \% \mathrm{Cu}$, among which are the tubular bracelet from A Urdiñeira and the bracelet from Cantonha. The small group of objects containing less than $0.2 \mathrm{wt} \% \mathrm{Cu}$ comprises the penannular bracelet from A Urdiñeira.

\subsection{The bracelets from Moimenta}

The two bracelets from Moimenta (nos. 5 and 6, Fig.1D), made by assembling several gold sheet components show the use of an alloy containing $c .2 \mathrm{wt} \% \mathrm{Cu}$ and c. $26 \mathrm{wt} \% \mathrm{Ag}$. The spot size of the XRF equipment used in this work is too large to analyse separately the joining areas and to ensure the analysis of the frame components without inclusion of solder containing areas. Data obtained for the small parts can only be considered as estimations, allowing just to suggest that some of the frame components were made from an alloy containing slightly lower Ag amounts than the band. The small increase in the copper contents observed in the joining areas was that expected for the use of a hard-soldering process.

Considering the bracelets dimension, decoration, and elemental composition, we can assume that the bracelets from Moimenta originally formed a pair. The amounts of $\mathrm{Cu}$ contained in the bracelets correspond to the use of an intentional gold alloy obtained by addition of this element to Ag-rich native gold or by addition of $\mathrm{Ag}$ and $\mathrm{Cu}$ to purer gold alloys. All the objects considered above tend to show that the earliest gold objects made in Galicia contain lower Ag contents, but the two pieces from Atios and the fragment of a diadem from As Silgadas contain more than $20 \mathrm{wt} \%$ Ag.

Two other bracelets from Galicia contain however, quite high copper and silver contents. Dated to the MBA (Montero and Rovira, 1991), the two-solid cast penannular bracelets from Lamela de Silleda (Pontevedra) are one of square-shaped section and the other of lozenge-shaped section with thinned terminals (Pingel, 1992). Two other BA solid gold penannular bracelets with rounded section from an undetermined context in the region of Lugo, also contain high copper contents (Martinón-Torres and Ladra, 2018). The diagram of Figure 9 shows that the bracelets from Moimenta, Lamela de Silleda and Lugo clearly contain much higher copper contents than all the other objects. The square-shaped section bracelet from Lamella de Silleda and the two bracelets from Moimenta also stand out by their high Ag contents. The other bracelet from Lamela de Silleda, despite its high copper content, contains a silver amount that, based on our data, is expected for Galician goldwork likewise the two uncontextualised bracelets from Lugo.

Montero \& Rovira (1991) attributed the composition of the bracelets from Lamella de Silleda to the introduction during the MBA of the use of intentional alloys, but none of the other productions discussed in this work contain such high silver and copper contents. In this work, we only came across high-Ag and Cu containing alloys when we considered the bracelet from Lebução, but, interestingly, Monge Soares et al. (2004) also pointed out the use of Ag-rich gold alloys in NW Portugal. If two analysed rivets from a BA knife found near Chaves contain 24-29 $\mathrm{wt} \% \mathrm{Ag}$ and $0.3-0.4 \mathrm{wt} \% \mathrm{Cu}$, and can thus be considered made from native gold, one IA torc that contains 26-27 $\mathrm{wt} \% \mathrm{Ag}$ has shown the presence of $1-2 \mathrm{wt} \% \mathrm{Cu}$ in the alloy. 
We plotted in the diagram of Figure 9 with the bracelets from Lamela de Silleda, Moimenta and Lugo the data obtained by several authors (Hartmann, 1982; García-Vuelta and Montero-Ruíz, 2007; Ladra and Martinón-Torres, 2009; Martinón-Torres and Ladra, 2018) for the elemental composition of eighteen IA gold torcs from Galicia. Four are unprovenanced torcs and the others are from Lugo (Castro de Viladonga, Castro da Ricadieira, Chaos do Castro and A Madorra) and A Coruña (Castrelo de Centroña, Castro de Bardaos, Castro das Modias and Castro de Flores).

Only the neck-ring compositions were considered. The plotted torcs contain up to $9 \mathrm{wt} \% \mathrm{Cu}$ (with an undefined 'gap' between 3.5 and $5.5 \mathrm{wt} \% \mathrm{Cu}$ ) and $\mathrm{Ag}$ contents ranging from 14 to $52 \mathrm{wt} \%$, confirming the regular use in Galicia during the IA of intentional gold alloys containing high copper and very high silver contents. The bracelet from Lebução is compositionally close to part of these torcs.

However, the five torcs from A Madorra, plotted separately in the diagram, contain less than $1 \mathrm{wt} \% \mathrm{Cu}$ and up to $21 \mathrm{wt} \% \mathrm{Ag}$, matching the Ag amounts expected for local native gold. In addition, only one of them contains more than $0.3 \mathrm{wt} \% \mathrm{Cu}$. From a general point of view, the plotted torcs seem to separate into two groups, because made from alloys that can be obtained by addition to native gold of either simply copper or copper and silver. Are contained in the first group, indicated in the diagram by a rectangle, the bracelet from Lamela de Silleda with rounded section and the two unprovenanced bracelets from Lugo. The second group (where the bracelet from Lebução would have been contained if plotted) comprises the pair of bracelets from Moimenta and the bracelet with square-shaped section from Lamela de Silleda.

\section{Concluding remarks}

The study of nine gold objects from Galicia allowed to gain further insight into their manufacture technologies and provided, by comparison with data on objects from the same area, an overview of the alloys employed in NW Iberia.

Although the technologies employed were known, we could reveal new details for the two sheet collars from Monte dos Mouros and for one of the bracelets from A Urdiñeira.

In addition to holes said for fastening, the small sheet collar from Monte dos Mouros has half holes of which two could have originally made one hole of undetermined function. The hammering folds on the back sheet of the two sheet collars, the incompletely cut bands, many of them still showing cutting leftovers, and the absence of marks of use-wear on the gold sheet and inside the holes bring out that these ornaments have been barely or not worn. Therefore, they may have only had a funerary or a ritual function.

For the penannular bracelet from A Urdiñeira, with holes on the terminals, we could reveal the presence of marks of use-wear both on the bracelet's body and inside the holes. This indicates that the object has been extensively worn and thus had not had a (entirely) ritual function. In addition, its decoration was made in two phases. Such as in EBA lunulae from the British Islands, over a motif is applied a less skilled one. The hatched triangles on the bracelet's terminals were expertly made first, and then partially remade, when the herringbone pattern was applied, but we are unable to comment on time and/or space distance between these two attempts of decoration.

The composition of the gold alloys has brought more information on the objects. The composition of early objects from Galicia (with $<0.2 \mathrm{wt} \% \mathrm{Cu}$ ) was used to establish a range of $\mathrm{Ag}$ contents consistent with local native gold. The two sheet collars from Monte dos Mouros are contained in this group and match the earliest Iberian goldwork. The penannular bracelet from A Urdiñeira is also contained in this group of alloys. Conversely, the tubular bracelet from the same hoard containing similar $\mathrm{Ag}$ amounts shows slightly higher $\mathrm{Cu}$ contents; it could be a later production. A similar increase of the $\mathrm{Cu}$ content is observed for the VE type bracelets, but not on chronological grounds (Perea, 2005). Both some of the VE type and some of the IA evolutions (as well as some torcs also from Galicia) are made from native gold, perhaps during a transition phase. The others are made from intentional gold alloys. The IA bracelets from Cantonha and Lebução contain even higher Ag and $\mathrm{Cu}$ amounts, which is regularly observed for torcs from Galicia (and from Asturias (García-Vuelta et al., 2020)) produced by the Castro Culture (Sastre, 2008).

In brief, when BA and IA torcs and bracelets from Galicia are considered, emerges a chemical pattern that suggests the use of two types of intentional alloys. One type, perhaps a first stage of production, is obtained by simple addition of $\mathrm{Cu}$ to local native gold, and the other type, characterised by higher $\mathrm{Ag}$ and $\mathrm{Cu}$ amounts, may correspond to the addition of both metals to native gold or (perhaps later) to the addition of $\mathrm{Ag}$ and/or $\mathrm{Cu}$ to recycled gold alloys. Further data on NW Iberian goldwork is however, necessary to check this possibility.

\section{Acknowledgements}

The authors would like to express their sincere gratitude to the Director of the Provincial Museum of Lugo, Dr Aurelia Balseiro, and to Beatriz Comendador-Rey, Professor at University of Vigo, for making possible the analytical study of the objects and for their guidance on this manuscript. 


\section{References}

Allan, G.C., Woodcock, J.T., 2001. A review of the flotation of native gold and electrum. Miner. Eng. 14(9), 931-962. https://doi.org/10.1016/S0892-6875(01)00103-0.

Allan, J.C., 1965. A mineração em Portugal na Antiguidade. Bol. de Minas 2 (3), 1-37.

Almagro-Gorbea, M., 1974. Orfebrería del Bronce Final en la Península Ibérica: el tesoro de Abía de la

Obispalía, la orfebrería tipo Villena y los cuencos de Axtroki. Trab.de Prehist. 31(1), 39-100.

Almagro-Gorbea, M., 1995. Celtic goldwork in the Iberian Peninsula, in: Morteani, G., Northover, J.P. (Eds.),

Prehistoric gold in Europe: Mines, Metallurgy and Manufacture. NATO ASI Series (Series E: Applied Sciences)

280. Springer, Dordrecht, pp. 491-5 01. https://doi.org/10.1007/978-94-015-1292-3.

Almagro-Gorbea, M., 1997. La Edad del Bronce en la Península Ibérica: periodización y cronología. Saguntum 30, 217-229. https://ojs.uv.es/index.php/saguntum/article/view/2139.

Armbruster, B., 1995. Rotary motion-lathe and drill. Some new technological aspects concerning Late Bronze Age goldwork from southwestern Europe, in: Morteani, G., Northover, J.P. (Eds.), Prehistoric gold in Europe: Mines, Metallurgy and Manufacture. NATO ASI Series (Series E: Applied Sciences) 280. Springer, Dordrecht, pp. 399-423. https://doi.org/10.1007/978-94-015-1292-3.

Armbruster, B., 1999. Techniques d'orfèvrerie préhistorique des tôles d'or en Europe atlantique des origines à l'introduction du fer, in: Cauuet, B. (Ed.), L'or dans l'antiquité. De la mine à l'objet, Aquitania Supplément 9 , pp.237-249. ISBN: 2-910763-03-X.

Armbruster, B., 2000. Goldschmiedekunst und Bronzetechnik: Studien zum Metallhandwerk der Atlantischen Bronzezeit auf der Iberischen Halbinsel. Monographies Instrumentum 15, Editions Monique Mergoil. ISBN: 2907303-27-9.

Armbruster, B., Bello Diéguez, J.M., Comendador Rey, B., Perea, A., 2004. Relaciones atlánticas en los inicios de la metalurgia. La gargantilla de tiras y el conjunto de gargantillas áureas de Cícere (Santa Comba, A Coruña, España), in: Perea, A., Montero, I., García Vuelta, O. (Eds.), Tecnología del Oro Antiguo: Europa y América. Madrid: Anejos de Archivo Español de Arqueología XXXII, pp.173-187. ISBN: 978-8400082932.

Armbruster, B., Comendador Rey, B., 2015. Early gold technology as an indicator of circulation processes in Atlantic Europe, in: Prieto Martínez, M. P., Salanova, L. (Eds.), The Bell beaker transition in Europe: mobility and local evolution during the 3rd millennium BC. Oxbow Books, Oxford, pp. 140-149.

Armbruster, B., Perea, A., 1994. Tecnología de herramientas rotativas durante el Bronce Final Atlántico. El depósito de Villena. Trab.de Prehist. 51 (2), 69-87. https://doi.org/10.3989/tp.1994.v51.i2.448.

Arndt, N., Kesler, S., Ganino, C., 2015. Metals and Society, An Introduction to Economic Geology, 2nd edition, Springer Mineralogy, Springer International Publishing, Switzerland.

Balseiro García, A., 1992. Orfebreria antiga da Terra de Melide. Bol. Cent. de Estudios Melidenses-Museo da Terra de Melide. 7, 15-26.

Balseiro García, A., 2003-2004. A Ourivería na Idade do Bonce. Bol. do MPL 11, 33-51.

Balseiro García, A., 2018. Colección de Ourivería Antiga. Servizo de Publicacións da Deputación de Lugo, ISBN 978-84-8192-560-9.

Bettencourt, A.M.S., 2010. La Edad del Bronce en el Noroeste de la Península Ibérica: un análisis a partir de las prácticas funerárias. Trab.de Prehist. 67(1), 139-173. https://doi.org/10.3989/tp.2010.10034.

Blas Cortina, M.A., 1994. El anillo áureo de tiras de la Mata'l Casare I y su localización megalítica. Madrider Mitteilungen 35, 143-160.

Blasco, C., Ríos, P., 2010. La función del metal entre los grupos campaniformes. Oro versus cobre. El ejemplo de la Región de Madrid. Trab.de Prehist. 67 (2), 359-372. https://doi.org/10.3989/tp.2010.10044

Boiron, M.C., Cathelineau, M., 1999. Les gisements aurifères, théories anciennes et nouvelles, or visible et invisible: exemples des gisements d'Europe de l'Ouest, in: Cauuet, B. (Ed.), L'or dans l'Antiquité de la mine à l'objet, Aquitania supplément 9, pp. 17-30. ISBN: 2-910763-03-X.

Borg, G., 2010. Warum in die Ferne schweifen? Geochemische Fakten und geologische Forschungsansätze zu Europas Goldvorkommen und zur Herkunft des Nebra-Goldes. Tagungen des Landesmuseums für Vorgeschichte Halle 5, 735-749.

Boyle, R.W., 1979. The Geochemistry of Gold and Its Deposits. Bulletin 280, Geological Survey of Canada, Ottawa. ISBN 0-660-01509-9.

Boyle, R.W., 1987. Gold: History and Genesis of Deposits, Boston Springer. ISBN: 978-1-4613-1969-6. Brandherm, D., 2007. Algunas reflexiones sobre el bronce in.icial en el noroeste peninsular. La cuestión del llamado horizonte 'Montelavar' Cuadernos de Prehistoria y Arqueología de la Universidad Autónoma de Madrid 33, 69-90. https://doi.org/10.15366/cupauam2007.33.004.

Butt, C.R.M., Hough, R.M., Verrall, M., 2020. Gold nuggets: the inside story. Ore and Energy Resource Geology 4-5, 100009, https://doi.org/10.1016/j.oreoa.2020.100009.

Cahill, M., 2006. John Windele's golden legacy-prehistoric and later gold ornaments from Co. Cork and Co. Waterford, Proceedings of the Royal Irish Academy 106C, 219-337. 
Cardoso, J.L., 2014. Bell-Beaker productions from the Portuguese territory. Estudos Arqueológicos de Oeiras 21, 295-348.

Cardoso, J.L., 2014-2015.The Bell-beaker complex in Portugal: an overview. O Arqueólogo Português Série V $(4 / 5), 275-308$.

Cardozo, M., 1957. Notícia de uma jóia antiga adquirida pelo Museu de 'Martins Sarmento'. Revista de Guimarães 67(1-2), 179-184. https://www.csarmento.uminho.pt/site/s/rgmr/item/56884.

Castro, X.M.D., Comendador Rey, B., 1998. El tesoro desencantado: As Silgadas (Caldas de Reis), Pontevedra: Concello de Caldas de Reis, D.L.

Castroviejo, R., 1995. A typological classification of Spanish precious metals deposits. Caderno Lab. Xeolóxico de Laxe Coruña. 20, 253-279.

Chapman, R.G., Mortensen, J.K., 2016. Characterization of Gold Mineralization in the Northern Cariboo Gold District, British Columbia, Canada, Through Integration of Compositional Studies of Lode and Detrital Gold with Historical Placer Production: A Template for Evaluation of Orogenic Gold Districts. Economic Geology 111, 1321-1345. https://doi.org/10.2113/econgeo.111.6.1321.

Chapman, R.J., Banks, D.A., Styles, M.T., Walshaw, R.D., Piazolo, S., Morgan, D.J., Grimshaw, M.R., SpenceJones, C.P., Matthews, T.J., Borovinskaya, O., 2020. Chemical and physical heterogeneity within native gold: implications for the design of gold particle studies. Mineralium Deposita. https://doi.org/10.1007/s00126-02001036-X.

Comendador Rey, B., 1998. Los inicios de la metalurgia en el Noroeste de la Península Ibérica. Brigantium, Museo Arqueóloxico e Histórico, A Coruña 11, 1-262.

Comendador Rey, B., Méndez Fernández, L., 2009. A recuperación dun contexto para un "tesouro" prehistórico: un proxecto de investigación e valorización patrimonial para o Monte Urdiñeira (Riós-A Gudiña, Ourense).

Revista AquaeFlaviae 41, 25-44.

Comendador Rey, B., Rodríguez Muñiz, V., Manteiga Brea, A., 2011. A estatua menhir do Tameirón no contexto dos resultados do proxecto de intervención arqueolóxica no Monte Urdiñeira e o seu contorno (A Gudiña- Riós, Ourense): in Vilaça, R. (Ed.), Estelas e estátuas-menires: da Pré à Proto-história. Actas das IV Jornadas Raianas, Sabugal, pp. 217-244. ISBN 978-989-95684-2-6.

Domergue, C., 1990. Les Mines de la péninsule Ibérique dans l'Antiquité romaine. Collection de l'École Française de Rome, Rome. ISBN 2-7283-0193-X.

Dube, R., 2006. Interrelation between gold and tin: A historical perspective. Gold Bull. 39, 103-113. https://doi.org/10.1007/BF03215537.

Echt, R., Thiele, W.R., Ivanov, I.S., 1991. Untersuchungen zur kupferzeitlichen Goldverarbeitung, in: Die kupferzeit als historische epoche, Saarbrücken Beitrage zur Altertumskunde 2, Bonn, verlag Dr. R. Habelt GmbH, pp. 633-692. ISBN: 978-3774924772.

Eluère, C. 1977. Les premiers ors en France, Bull. Soc. Préhist. Fr. 74 (1), 390-419.

Eluère, C., 1982. Les Ors préhistoriques. L'Age du bronze en France, Picard, Paris. ISBN: 978-2708400856.

Eluère, C., 1983. Prehistoric goldwork in Western Europe. Gold Bull. 16 (3), 82-91.

https://doi.org/10.1007/BF03214628.

Eluère, C., 1986. L'orfèvrerie préromaine au musée de Cluny. La revue du Louvre et des musées de France 2, 97-106.

Eluère, C., Gomez de Soto, J., 1990. Bracelets, colliers, boucles. Typologies des objets de l'âge du Bronze en France 7, Société préhistorique française, Commission du bronze, Paris.

Fernández-Lozano, J., Palao-Vicente, J.J., Blanco-Sánchez, J.A., Gutiérrez-Alonso, G., Remondo, J., Bonachea, J., Morellón, M., González-Díez, A., 2019. Gold-bearing Plio-Quaternary deposits: Insights from airborne LiDAR technology into the landscape evolution during the early Roman mining works in north-west Spain. Journal of Archaeological Science: Reports 24, 843-855. https://doi.org/10.1016/j.jasrep.2019.03.001.

Galán, E., 2017. Trabajos de oro perdidos. Noticia de dos antiguos hallazgos áureos y su relación con el Museo Arqueológico Nacional. Bol. del Museo Arqueológico Nacional 36, 35-54.

Gale, N.H., Stos-Gale, Z.A., 1981. Ancient Egyptian Silver. J. Egypt. Archaeol. 6, 103-115.

https://doi.org/10.1177/030751338106700110.

Gandois, H., Barthet, L., 2015. Le mobilier du ‘dolmen de Saint-Père-en-Retz' (Loire-Atlantique): nouveaux éléments de réflexion. Rev. Archéol. de l'Ouest 32, 83-95. https://doi.org/10.4000/rao.2914.

García-Vuelta, O., Montero-Ruíz, I., 2007. Aportaciones analíticas sobre orfebrería castreña: problemas de caracterización en piezas de la colección del Museo Arqueológico Nacional (Madrid). Conimbriga XLVI, 89115. http://dx.doi.org/10.14195/1647-8657_46_5

García-Vuelta, O., Montero-Ruiz, I., Valdés, A.V., 2020. Orfebrería castreña en el Museo Arqueológico de Asturias (Oviedo): aproximación a su caracterización arqueométrica y problemas de estudo. Trab.de Prehist. 77 (1), 163-183. https://doi.org/10.3989/tp.2020.12252. 
Gomez de Soto, J., 1999. Habitats et nécropoles des âges des métaux en Centre-Ouest et en Aquitaine. La question de l'or absent, in : Cauuet, B. (Ed.), L'or dans l'antiquité. De la mine à l'objet. Aquitania Supplément 9 , pp. 337-346. ISBN: 2-910763-03-X.

Guerra, M., Longelin, S., Pessanha, S., Manso, M., Carvalho, L., 2014. Development of a combined portable xray fluorescence and Raman spectrometer for in situ analysis. Rev. Sci. Instrum. 5, 063113 -1-9.

https://doi.org/10.1063/1.4883188.

Guerra, M.F., 2004. The circulation of South American precious metals in Brazil at the end of the 17th century. J. Archaeol. Sci. 31, 1225-1236. https://doi.org/10.1016/j.jas.2004.03.018.

Guerra, M.F., 2008. An overview on the ancient goldsmith's skill and the circulation of gold in the past: the role of X-ray based techniques. X-ray Spectrom. 37(4), 317-327. https://doi.org/10.1002/xrs.1013.

Guerra, M.F., 2018. Physicochemical approaches to gold and silver work: an overview, in: Sabbatini, L., van der Werf, D. (Eds.), Chemical Analysis in Cultural Heritage, W. De Guyter, Berlin/Boston, pp. 307-330.

https://doi.org/10.1515/psr-2018-0015.

Guerra, M.F., 2021. Reflections on gold: colour and workshop practices in Egypt. In: M.F. Guerra, Ma.

Martinón-Torres, S. Quirke (Eds.), Ancient Egyptian gold. Archaeology and science in jewellery (3500-1000

BC). Upcoming.

Guerra, M.F., Radtke, M., Reiche, I., Riesemeier, H., Strub, E., 2008. Analysis of trace elements in gold alloys by SR-XRF at high energy at the BAMline. Nucl. Instrum. Meth. B 266 (2008) 2334-2338.

https://doi.org/10.1016/j.nimb.2008.03.008.

Guerra, M.F., Tissot, I., 2016. Bronze Age and Iron Age gold torcs and earrings from the Iberian Atlantic façade: a non-invasive multi-analytical approach to the characterization of the alloys and the corrosion. X-Ray Spectrom. 45(1), 5-13. https://doi.org/10.1002/xrs.2628.

Harris, J.R., 1961. Lexicographical studies in Ancient Egyptian minerals. Deutsche Akademie der Wissenschaften zu Berlin, Institut für Orientforschung, vol. 54. Berlin: Akademie Verlag.

Harrison, F.A., 1931. Ancient mining activities in Portugal. The Mining Magazine 45(3), 137-145.

Harrison, R.J., 1974. Ireland and Spain in the Early Bronze Age: Fresh Evidence for Irish and British Contacts with the Proto-Atlantic Bronze Age in Spain in the Second Millennium B.C. The Journal of the Royal Society of Antiquaries of Ireland 104, 52-73.

Hartmann, A., 1971. Análises de alguns objectos pré-históricos de ouro, procedentes do Norte de Portugal. Revista de Guimarães 81(1-2), 129-138.

Hartmann, A., 1982. Prähistorische Goldfunde aus Europa II. Spektralanalytische Untersuchungen und deren Auswertung. Studien zu den Anfängen der Metallurgie 5, Ed. Mann, Berlin. ISBN: 978-3786112877.

Hauptmann, A., Klein, S., Paoletti, P., Zettler, R.L., Jansen, M., 2018. Types of Gold, Types of Silver: The Composition of Precious Metal Artifacts Found in the Royal Tombs of Ur, Mesopotamia. Zeitschrift für Assyriologie und Vorderasiatische Archäologie 108(1), 100-131. https://doi.org/10.1515/za-2018-0007. Healy, J.F., 1979. Mining and Processing Gold Ores in the Ancient World. J. Met. 31, 11-16, Hough, R.M., Butt, C.R.M., Fischer-Bühner, J., 2009. The Crystallography, Metallography and Composition of Gold. Elements 5, 297-302. https://doi.org/10.2113/gselements.5.5.297.

Inverno, C.M.C., 2011. Comparação entre os jazigos de ouro do tipo orogénico (ou mesotermais) e os jazigos de ouro associados a intrusão. Algumas extrapolações para Portugal. Cadernos Lab. Xeolóxico de Laxe Coruña 36, 99-156.

Jones, R.S., Fleischer, M., 1969. Gold in minerals and the composition of native gold. Circular 612, Geological Survey, Washington D.C.,U.S. https://doi.org/10.3133/cir612.

Ladra, L., Martinón-Torres, M., 2009. Variacións tecnolóxicas e preferencias culturaisestudo analítico dos ouros do Castro de Viladonga. CROA: Bol. da Asociación de Amigos do Museo do Castro de Viladonga 19, 32-43. Ladra, L., Silva, A.C., Sousa, M.J., 2003. Notas sobre uma nova lâmina áurea de tiras do norte de Portugal. Portugalia 24, 53-64.

Lehrberger, G., 1995. The Gold Deposits of Europe, in: Morteani, G., Northover, J.P. (Eds.), Prehistoric Gold in Europe, NATO ASI Series. Series E: Applied Sciences 280, Springer, Dordrecht, pp.115-144, ISBN: 978-07923-3255-8.

Leusch, V., 2019. Zur Rolle der kupferzeitlichen Goldmetallurgie im westlichen Schwarzmeerraum Untersuchungen der Goldfunde aus dem Gräberfeld Varna I (Bulgarien), PhD Dissertation, Fakultät der Eberhard Karls, Universität Tübingen.

Lillios, K., 2019. The Emergence of Ranked Societies: The Late Copper Age to Early Bronze Age (2,500-1,500 BCE), in: The Archaeology of the Iberian Peninsula: From the Palaeolithic to the Bronze Age. Cambridge World Archaeology, Cambridge University Press, Cambridge, pp. 227-292. ISBN: 978-110-7113-34-3.

Lopéz Cuevillas, F., Bouza Brey, F., 1992. Os Oestrimnios os Saefes e a Ofiolatría en Galiza. Ed. facsímil co gallo do ano de Brouza-Brey e do Día das Letras Galegas 1929. Santiago de Compostela: Universidade, Instituto de Estudios Galegos "Padre Sarmiento". 
MacKenzie, D., Craw, D., Mortensen, J.K., 2019. Orogenic gold deposits in the Variscan belt in northwestern Iberia, in: Proceedings of the 15th SGA Biennial Meeting "Life with Ore Deposits on Earth", vol 2. Glasgow, Scotland, pp.736-738.

Maluquer de Motes, J., 1970. Desarrollo de la orfebrería prerromana en la Península Ibérica. Pyrenae: revista de prehistòria i antiguitat de la Mediterrània Occidental 6, 79-110. ISSN 0079-8215.

Martinón-Torres, M., Ladra, L., 2018. A ourivería prehistórica no Museo Provincial de Lugo: una aproximación desde a química, in Balseiro, A. (Ed.), Colección de Ourivería Antiga, Servizo de Publicacións da Deputación de Lugo, pp. 46-59, ISBN 978-84-8192-560-9.

Martins, C.M., 2010. Mecanismos de diferenciação na Segunda Idade do Ferro, in: C.M.B. Martins (Ed.), Mineração e Povoamento na Antiguidade no Alto Trás-os-Montes Ocidental, Edições Afrontamento, Santa Maria da Feira, pp. 61-78.

Martins, C.M.B., 2008. Exploração aurífera romana em Portugal. Férvedes, Museo de Prehistoria y Arqueoloxía de Vilalba 5, 413-422.

Meller, H., 2019. Reflections on the Dieskau gold find and its possible origin from the Early Bronze Age Bornhöck barrow near Dieskau in the Saalekreis district. Studia Hercynia 33 (2), 9-21.

Menez, Y., Fily, M., Dupré, M., 2005. Le site de Kerboar à Saint-Igeaux (Côtes-d'Armor). Nouvelles découvertes, Rapport de sondage RAP02132, Service régional de l'archéologie de Bretagne.

Moles, N.R., Chapman, R.J., Warner, R.B., 2013. The significance of copper concentrations in natural gold alloy for reconnaissance exploration and understanding gold-depositing hydrothermal systems. Geochemistry: Exploration, Environment, Analysis 13 (2), 115-130. https://doi.org/10.1144/geochem2011-114. Molina, S.P., 1996. Los torques castreños del noroeste de la Península Ibérica. Complutum 7 (1996) 195-224. https://revistas.ucm.es/index.php/CMPL/article/view/CMPL9696130195A.

Monge Soares, A.M., Araújo, M.F., Alves, L.C., 2004. Análise química não-destrutiva de artefactos em ouro pré e proto-históricos: alguns exemplos. Revista Portuguesa de Arqueologia 7(2), 125-138.

Monteagudo, L., 1953. Orfebrería del NW Hispánico en la Edad del Bronce. Arch. Espan. Arqueol. XXVI 88, 295.

Montero, I., Rovira, S., 1991. El oro e sus aleaciones en la orfebrería prerromana. Arch. Espan. Arqueol. 64, 721. https://doi.org/10.3989/aespa.1991.v64.496.

Montero-Ruiz, I., Murillo-Barroso, M., Hook, D., 2019. The production, frequency and use of tin bronze in the Early Bronze Age El Argar culture. Bol. del Museo Arqueológico Nacional 38, 9-26.

Moucha, V., 2005. Hortfunde der frühen Bronzezeit in Böhmen. Praha. Archäologisches Institut der Akademie der W issenschaften der Tschechischen Republik.

Murgia, A., Roberts, B.W., Wiseman, R., 2014. What have metal-detectorists ever done for us? Discovering Bronze Age gold in England and Wales. Archäol. Korresponden. 44 (3), 353-367.

Murillo-Barroso, M., Eleazar Costa Caramé, M., Díaz-Guardamino Uribe, M., García Sanjuán, L., Mora Molina, C., 2015. A Reappraisal of Iberian Copper Age Goldwork: Craftmanship, Symbolism and Art in a Non-funerary Gold Sheet from Valencina de la Concepción. Camb. Archaeol. J. 25(3), 565-596.

https://doi.org/10.1017/S0959774314001127.

Noronha, F., Ramos, J.M.F., 1993. Primary gold mineralisation in north of Portugal. Some reflexions. Cuaderno Lab. Xeolóxico de Laxe Coruña 18, 133-146.

Perea, A., 1991. Orfebrería prerromana. Arqueología del oro. Comunidad de Madrid. Caja Madrid, ISBN: 844510-385-7.

Perea, A., 1995. La metalurgia del oro en la fachada atlántica peninsular durante el Bronce Final: interacciones tecnológicas. Complutum 5, 69-78.

http://www.ucm.es/BUCM/revistas/ghi/11316993/articulos/CMPL9595220069A.PDF.

Perea, A., 2005. Mecanismos identitarios y de construcción de poder en la transición Bronce-Hierro. Trab.de Prehist. 62 (2), 91-104. https://doi.org/10.3989/tp.2005.v62.i2.70.

Perea, A., Armbruster, B., 2008. Tradición, cambio y ruptura generacional. La producción orfebre de la fachada atlántica durante la transición Bornce-Hierro de la Penínsuña Ibérica, in Celestino Pérez, S., Fontanals N.R., Armada Pita, X.L. (Eds.), Contacto cultural entre el Mediterráneo y el Atlántico: (siglos XII-VII ane): la precolonización a debate, CSIC, Madrid, pp. 509-522. ISBN: 978-84-00-08689-3.

Pérez-Romero, A., Perea, A., Iriarte, E., Francés-Negro, M., Álvarez-Fernández, A., Arsuaga, J.L., Carretero, JM., 2018. Estudio arqueométrico y contextual del brazelete de oro tipo Villena/Estremoz de la Cueva del Silo Sierra de Atapuerca, Burgos, España. Trab.de Prehist. 75 (1), 163-171. https://doi.org/10.3989/tp.2018.12210. Pingel, V., 1991. O Tesouro de Caldas de Reis e a ouriveria da época do bronce, in: Galicia no Tempo. Santiago de Compostela, Xunta de Galicia, pp. 43-58.

Pingel, V., 1992. Die vorgeschichtlichen Goldfunde der Iberischen Halbinsel - Eine archäologische Untersuchung zur Auswertung der Spektralanalysen. Madrider Forschungen 17, (W.de Gruyter) Berlin. ISBN: 3110123371 . 
Plenderleith, H.J., 1934. Metals and metal technique, in: C.L. Woolley (Ed.), Ur Excavations II, Publications of the joint Expedition of the British Museum and of the Museum of the University of Pennsylvania to Mesopotamia, London, pp. 284-99.

Radtke, R., Buzanich, A.G.G., Reinholz, U., Riesemeier, H., Scharf, O., Scholz, P., Guerra, M.F., 2016. Double Dispersive X-Ray Fluorescence (D2XRF) Based on an Energy Dispersive pnCCD Detector for the Detection of Platinum in Gold. Microchem. J. 125, 56-61. https://doi.org/10.1016/j.microc.2015.10.039.

Rovira Hortalà, M.C., Borrell, F., Oliva, M., Saña, M., Vicente, O., Alcalde, G., 2014. Early gold remains in the north-east of the Iberian Peninsula: in Metals of power - Early gold and silver. Landesmuseums für Vorgeschichte Halle 11(2), 541-545. ISBN: 3944507053.

Ruiz-Galvez, M., 1995. From Gift to Commodity. The changing meaning of precious metals in the later Prehistory of the Iberian Peninsula, in: Morteani, G., Northover J.P. (Eds.), Prehistoric gold in Europe: Mines, Metallurgy and Manufacture, NATO ASI Series (Series E: Applied Sciences) 280. Springer, Dordrecht, M., 4563. https://doi.org/10.1007/978-94-015-1292-3.

Russell Cortez, F., 1954. O bracelete de Estremoz. Nummus 2 (6), 71-73.

Sánchez Palencia, F.J., González, Y.A., González, L.F.L, 1996. La minería aurífera en Gallaecia, in: El oro y la orfebrería prehistórica de Galicia. Deputación Provincial de Lugo, pp. 9-40. ISBN 84-8192-086-X.

Sastre, I., 2008. Community, Identity, and Conflict: Iron Age Warfare in the Iberian Northwest. Curr. Anthropol. 49(6), 1021-1051. https://doi.org/10.1086/529423.

Schüle, W., 1976. Der Bronzezeitliche Schatzfund von Villena (Prov. Alicante). Madrider Mitteilungen 17, $142-$ 159.

Silva, A.C., Tavares da Lopes, C., Baptista, A., 1984. Depósito de fundidor do final da Idade do Bronze do Castro da Senhora da Guia (Baiões, S. Pedro do Sul, Viseu). Lucerna: colectânea de estudos de homenagem a D. Domingos de Pinho Brandão, noextr. 73-95. http://hdl.handle.net/10216/56618.

Silva, A.C.F., 1986. A cultura castreja no noroeste de Portugal. Paços de Ferreira, Museu Arqueológico de Citânia de Sanfins. ISBN: 978-972-9408-28-1.

Siret, L., Siret, H., 1887. Las primeras edades del metal en el sudeste de España. Edición facsimilar, Museo Arqueológico de Murcia, Murcia, 2006.

Siret, L., Siret, H., 1988. Les Premiers Ages Du Metal Dans Le Sud-Est De L'Espagne, Extrait de la Revue des questions scientifiques, Imprimerie Polleunis, Ceuterick et Lefébure, Bruxelles.

Soler García, J.M., 1965. El tesoro de Villena. Excavaciones Arqueológicas en España 36: Ministerio de Educación Nacional, Madrid.

Soler García, J.M., 1969. El oro de los tesoros de Villena. Serie de Trabajos Varios 36, Servicio de Investigación Prehistórica, CSIC, Valencia. http://mupreva.org/pub/67/es.

Spiering, E.D., Pevida, L.R., Maldonado, C., González, S., Garcia, J., Varela, A., Arias, D., Martín-Izard, A., 2000. The gold belts of western Asturias and Galicia (NW Spain). J. Geochem. Explor. 71(2), 89-101.

https://doi.org/10.1016/S0375-6742(00)00147-3.

Spiridonov, E., Yanakieva, D., 2009. Modern mineralogy of gold: overview and new data. ArcheoSciences, Rev. A. 33, 67-73. https://doi.org/10.4000/archeosciences.2034.

Stanaway, K.J., 2012. Ten placer deposit models from five sedimentary environments. Applied Earth Science. Transactions of the Institutions of Mining and Metallurgy, Section B 121 (1), 43-51.

https://doi.org/10.1179/1743275812Y.0000000020.

Taylor, J.J., 1969. Early Bronze Age Gold Neck-Rings in Western Europe. Proceedings of the Prehistoric Society 34, 259-265. https://doi.org/10.1017/S0079497X00013906.

Taylor, J.J., 1979. Early Bronze Age technology and trade: the evidence of Irish gold. Expedition 21, 23-32.

Taylor, J.J. 1980. Bronze Age Goldwork of the British Isles, Cambridge University Press, Cambridge. ISBN: 052-120-802-5.

Taylor, J.J., 1994. The First Golden Age of Europe Was in Ireland and Britain (Circa 2400-1400 B.C.). Ulster J. Archaeol. 57, 37-60. https://www.jstor.org/stable/20568208.

Tissot, I., Guerra, M.F., 2017. Composition of Bronze Age Gold Bracelets from the Portuguese Area, in: Montero Ruiz, I., Perea, A. (Eds.), Archaeometallurgy in Europe IV, Bibliotheca Prehistorica Hispana 33, Consejo Superior de Investigaciones Científicas, Madrid, pp. 159-167. ISBN 978-84-00-10287-6.

Tissot, I., Tissot, M., Manso, M., Alves, L.C., Barreiros, M.A., Marcelo, T., Carvalho, M.L., Corregidor, V., Guerra, M.F., 2013. The earrings of Pancas treasure: analytical study by X-ray based techniques - a first approach. Nucl. Instrum. Meth. B 306, 236-240. https://doi.org/10.1016/j.nimb.2012.11.054.

Valério, P., Soares, A.M.M., Araújo, M.F., Carvalho, A.F., 2017. Micro-EDXRF investigation of Chalcolithic gold ornaments from Portuguese Estremadura. X-Ray Spectrom. 46(4), 252-258.

https://doi.org/10.1002/xrs.2764.

Vekemans, B, Janssens, K., Vincze, L., Adams, F., Van Espen, P., 1994. Analysis of X-ray Spectra by Iterative Least Squares (AXIL): New Developments. X-Ray Spectrom. 23, 278-285. 
Table 1 - List of the analysed objects in the collection of the Provincial Museum of Lugo, including museum accession number, find site, dimensions (width, height, and diameter) and weight.

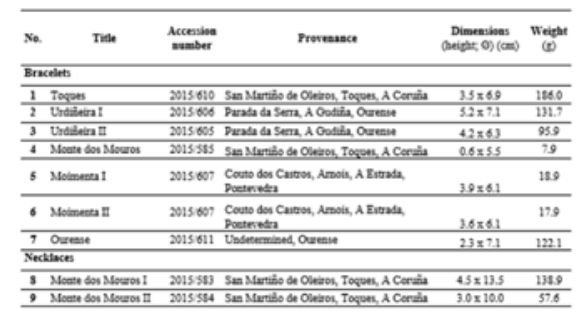

Table 2 - Average elemental composition obtained by XRF for the bracelets and sheet collars studied in this work, normalised to $100 \mathrm{wt} \%$.

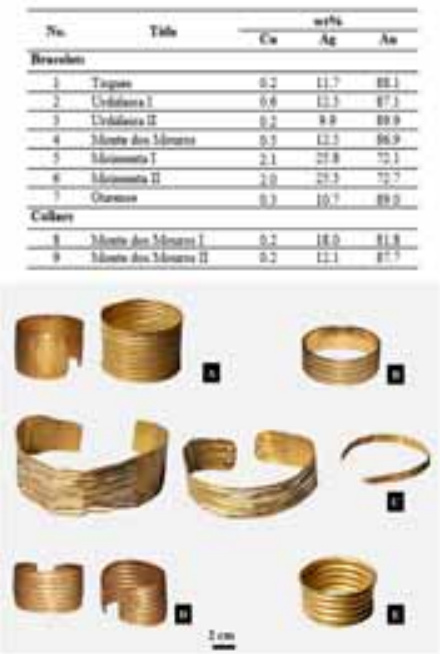

Figure 1 - Objects in the collection of the Provincial Museum of Lugo analysed in this work: (A) the bracelets from A Urdiñeira, (B) the Ourense bracelet, (C) the hoard of Monte dos Mouros, (D) the bracelets from Moimenta and (E) the bracelet from Toques.

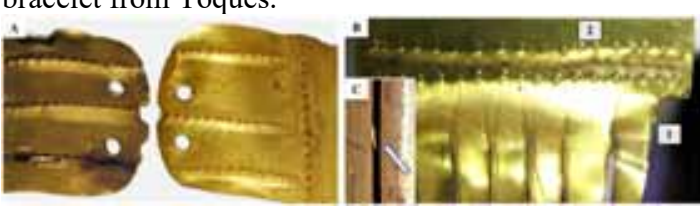

Figure 2 - Details of the small sheet collar from Monte dos Mouros (no. 9) showing: (A) the holes of the aligned terminals and (on the left) hammering folds on the back sheet; (B) the missing band (1), and one triple row of punched dots (two made from the inside and one from the outside) with the strip cutting tool marks overlapping the punched dots (2); and (C) one of the cutting leftovers.

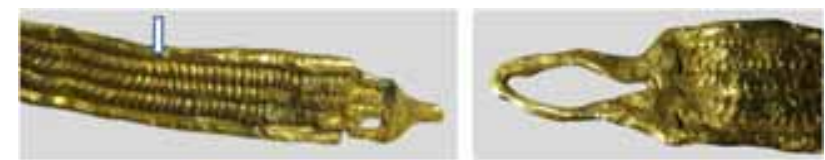

Figure 3 - The "hook-and-loop" fastening system of the bracelet from Monte dos Mouros (no. 4) where the arrow indicates the change of sense of the decoration.

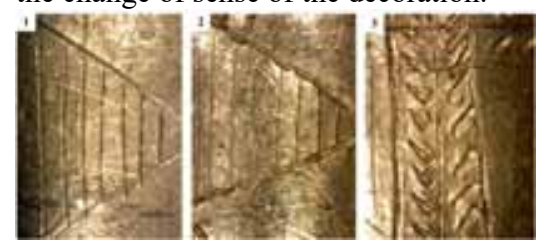

Figure 4 - Details of the penannular bracelet from A Urdiñeira (no.3) showing: (A) and (B) the hatched triangles and the different tool marks and $(\mathrm{C})$ the deeply incised herringbone pattern. 


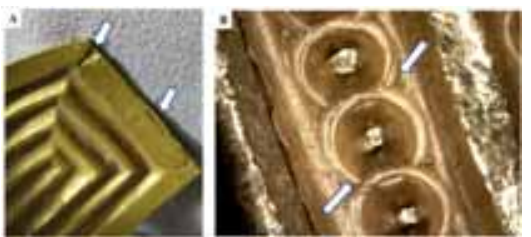

Figure 5 - (A) The overlapping of the circular tool used to make the conical spikes that decorate the Ourense bracelet (no.7). (B) Back of one of the bracelets from Moimenta (no.5) showing the joining of the frame to the body.

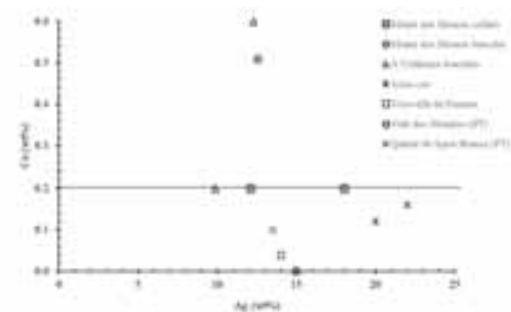

Figure 6 - The $\mathrm{Cu}$ and $\mathrm{Ag}$ contents obtained by XRF for the bracelets and sheet collars from Monte dos Mouros and A Urdiñeira, compared to Iberian EBA objects cited in the text that were analysed by Hartmann (1982). The line indicates the highest $\mathrm{Cu}$ content observed for the EBA objects.

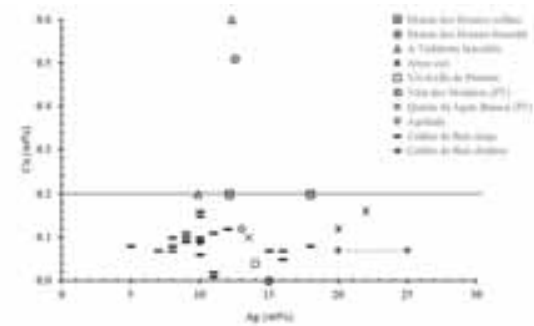

Figure 7 - The objects plotted in Figure 6 compared to data published by Hartmann (1982) for the bracelets contained in the Treasure of Agolada and in hoard 1 from Caldas de Reis. The line indicates the highest $\mathrm{Cu}$ content observed for the NW Iberia EBA objects.

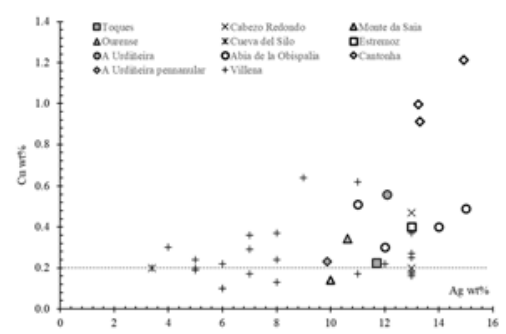

Figure 8 - The $\mathrm{Cu}$ and $\mathrm{Ag}$ contents obtained by XRF for the bracelets from Toques, Ourense and A Urdiñeira compared to the composition of Iberian VE type bracelets mentioned in the text (Pérez-Romero et al., 2018; Tissot and Guerra, 2017; Hartamann, 1982; Hartmann, 1971).

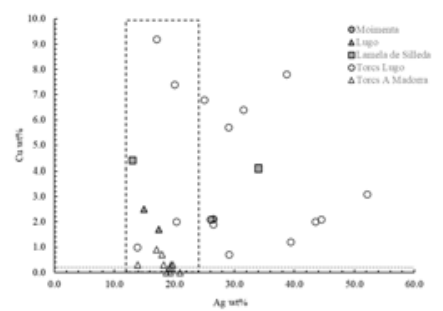

Figure 9 - The $\mathrm{Cu}$ and $\mathrm{Ag}$ contents obtained by XRF for the bracelets from Moimenta compared to data published for other bracelets and torcs from Galicia (Hartmann, 1982; García-Vuelta and Montero-Ruíz, 2007; Ladra and Martinón-Torres, 2009; Martinón-Torres and Ladra, 2018). The line indicates the highest $\mathrm{Cu}$ content observed for the NW Iberia EBA objects. The rectangle contains the objects showing Ag contents expected for native gold from Galicia. 